American Journal of Applied Sciences 6 (6): 1169-1174, 2009

ISSN 1546-9239

(C) 2009 Science Publications

\title{
Sea Level Threat in Tuvalu
}

\author{
Than Aung, Awnesh Singh and Uma Prasad \\ Physics Division, University of the South Pacific, Laucala Campus, Suva, Fiji
}

\begin{abstract}
Problem statement: Recently the impacts of climate change, in particular, sea level rise, had been a major concern for many Pacific island countries. In early 2000, there were a series of media coverage over sea level rise issues using Tuvalu as an example. The daily life of Tuvalu revolves around the ocean and the immediate threat on the islands people, economy, environment and its islands is of concern to the Tuvalu government. The Tuvalu government has concluded that Tuvalu was destined to become the first nation to be sunk by global warming because it is one of the smallest and lowest-lying countries in the world. Approach: In this study, sea level data from the Australian project will be focussed on despite the fact that the length of data is not sufficiently long. The AusAID funded South Pacific Sea Level and climate monitoring project was set up in response to concerns raised by Pacific island countries over the potential impacts of an enhanced greenhouse effect on climate and sea levels in the South Pacific for 20 years. Results: Based upon the 151/2 years of sea level data from the project, the sea level rise rate in Tuvalu as at september 2008 was $5.9 \mathrm{mM} \mathrm{year}^{-1}$. This was about four times higher than the global average of $1-2 \mathrm{~mm} \mathrm{year}^{-1}$. Sea level in the Tuvalu area had risen approximately $9.14 \mathrm{~cm}$ since the inception of the project $15 \frac{1}{2}$ years ago. However, it was to be noted that the land is quite stable and the rate of land sinking is $-0.06 \mathrm{mM}$ year ${ }^{-1}$ only. Accordingly, there was no significant impact on the sea level trends. Conclusion: Although the data length is just over 15 years, the sea level trend values do not fluctuate significantly since 1999. It simply indicated that the rate of sea level rise in the Tuvalu region was not accelerating as anticipated by the community.
\end{abstract}

Key words: sea level, greenhouse effect, climate change, AusAID, Tuvalu, Pacific Islands

\section{INTRODUCTION}

The plight of small island states has focussed global attention on the impacts of climate change and in particular, sea level rise for the last few years. Until recently, scientific research in the region has been sparsely scattered, making it difficult to establish longterm trends. However, the inhabitants of every Pacific island atoll and island insist that what they are observing today is in many cases very different from what they knew one or more decades ago. These disruptive changes are consistent with many of the anticipated impacts of global and regional changes.

In chapter 32 (the last act of god) of Flannery's ${ }^{[2]}$ book, the author commented that the inhabitants of lands, immediately vulnerable to climate change, are five atoll countries; Kiribati, Maldives, Marshall Islands, Tokelau and Tuvalu. As a result of the destruction of the world's coral reefs, rising sea and the intensifying weather events already in train, it seems inevitable that these nations will be destroyed by climate change during the course of this century.
The government of Tuvalu's request and concerns over the impacts of climate change on its people, economy, environment and its islands are generally reasonable and valid. This study is an attempt to address some of the issues on climate change variability and sea level rise raised by the Tuvalu government, although there is no way to provide a comprehensive or in-depth study on the impacts of climate, variability and sea level rise in Tuvalu. The media outcry reached its climax in 2002-2003 and the authors waited until the situation calmed down and a few more years of sea level data for Tuvalu was obtained for a better trend calculation.

Background history: The Pacific island of Tuvalu is located in the central Pacific, close to the intersection of the equator and the International Date Line. To be exact, Tuvalu is located at $8^{\circ} \mathrm{S}$ latitude and $178^{\circ} \mathrm{E}$ longitude. Figure 1 generally shows the group of Tuvalu islands. A Spanish explorer spotted the island in the 16th century, but it was another 200 years before storms pitched the first missionary on to Tuvalu's coral atolls, which were named the Ellice Islands and subsumed into British Empire.

Corresponding Author: Awnesh Singh, Physics Division, University of the South Pacific, Laucala Campus, Private Bag, Suva, Fiji Tel: 679-3232645 Fax: 679-3231511 


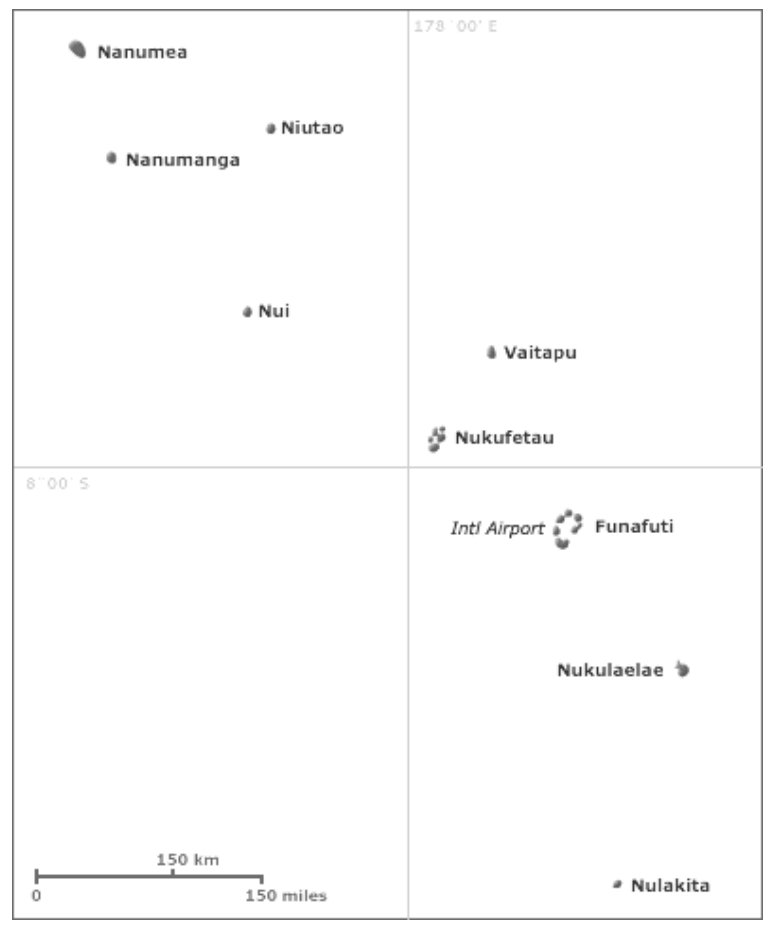

Fig. 1: Map of Tuvalu

Tuvalu's total land area is $26 \mathrm{~km}^{2}$ comprising of nine atolls located in the western central Pacific Ocean. The coral chain is $580 \mathrm{~km}$ in length and is made up of the following islands: Funafuti, Nukufetau, Nukulaelae, Nanumea, Niutao, Nanumanga, Nui, Vaitupu and Niulakita, all low-lying with a maximum elevation of $4.6 \mathrm{~m}$ above the mean sea level in Niulakita.

Geologically, the Tuvaluan islands first emerged as volcanoes about 64 million years ago resulting from large under seas eruptions, which took place in the Late Mesozoic-Early Cenozoic times. The studies ${ }^{[6]}$ carried out in 1957 clearly show that reef and lagoon limestone formed the top layer to a depth of about $1000 \mathrm{~m}$ below the surface. Drilling data at Funafuti to a depth of $338 \mathrm{~m}$ reveal the following lithology: 0-200 m-reef associated with lime stone; 200-338 m-calcareous mud and dolomitic limestone. The upper metres consist of coral sand and coral gravel, in a matrix of lime mud. Results from seismic observations show a thickness of the coral cap of approximately $1000 \mathrm{~m}$ on Funafuti and $770 \mathrm{~m}$ at Nukufetau.

\section{MATERIALS AND METHODS}

The Australian project [South pacific sea level and climate monitoring project]: In response to concerns raised by the Pacific island countries over the potential

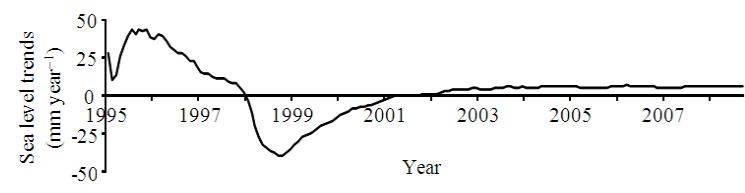

Fig. 2: Sea level trend diagram for Tuvalu

impacts of an enhanced greenhouse effect on climate and sea levels in the South Pacific region, the South Pacific Sea Level and Climate Monitoring Project was set up in early 1990s. It has been fully funded by AusAID for the forum region. As part of the project, a SEAFRAME (SEAlevel Fine Resolution Acoustic Measuring Equipment) gauge was installed in Funafuti, Tuvalu in March 1993. The gauge has been returning high resolution, good scientific quality data since then.

SEAFRAME gauges not only measures sea level by two independent means, but also a number of ancillary variables, such as air and water temperatures, wind speed, wind direction, wind gust and atmospheric pressure. There is an associated programme of levelling to determine vertical movement of the sea level sensors due to local land movement. Continuous Global Positioning System (CGPS) measurements are also now being made to determine the vertical movement of the land with respect to the International Terrestrial Frame.

The process of sea level data analysis and trend calculation is as follows: to begin the analysis, the first year of observed hourly values of sea level for a location (say Tuvalu in this case) was analysed for a trend value. The full harmonic model of 112 tidal constituents was applied so as to identify the tidal component and at the same time a trend analysis is conducted. The next stage begins by adding just one month of additional hourly data, repeating the analysis and plotting the trend result in Fig. 2. The process is repeated, adding one month at a time to the data set presented for analysis until the entire available data set is exhausted. Each estimate given and plotted is the sea level trend evaluated over the entire preceding time series, regardless of the start date for a particular station.

\section{RESULTS}

Recent sea level trends in Tuvalu (over 15 years land based data): It is to be noted from Fig. 2 that the early part of the trend line was not stabilised. But we can see that the estimates are becoming progressively smaller in magnitude and that the lines are becoming smoother and stable. The length of the data is slightly more than 15 years; some significant fluctuations in the trends do 
not show any more. During the last 15 years, there were at least four El Niño periods; one was prolonged, one was very severe and the others were weak ones. It is also to be noted that the gauges located close to the equatorial wave guides and in particular those near to the western boundary of the Pacific, will undergo substantial fluctuations during ENSO episodes. Based upon these 15 years long sea level data ${ }^{[9]}$, the rate of sea level rise in the Tuvalu area is $5.9 \mathrm{mM}$ per year (as at September 2008). The value is very much stable, the variation from the previous months is minimal and as small as $0.1 \mathrm{~mm}$ year $^{-1}$. This local value is approximately four times larger than the global average of 1-2 mM year ${ }^{-1}$. During these 15 years, sea level in Tuvalu rose approximately $91.4 \mathrm{mM}$ or $9.14 \mathrm{~cm}$. When we look at the surveying data for the vertical land movement, the SEAFRAME station area is sinking $0.61 \mathrm{~mm}$ for the 10 years period. Accordingly, the rate of land sinking is on $-0.06 \mathrm{~mm}$ year $^{-1}$ and there is no significant impact on the sea level rise trends.

Figure 3 and 4 show the barometric pressure anomalies and the sea level anomalies. It clearly indicates the inverted barometric pressure effect on sea level during the 1997/98 severe El Niño ${ }^{[14]}$.

In summary, the following table (Table 1) will highlight the critical values of sea level issue in the Tuvalu area.

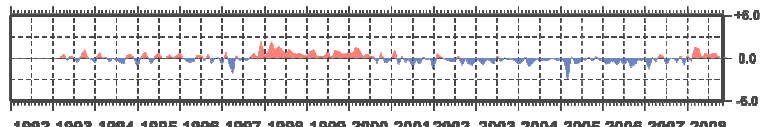

19921993199419951996199719981999200020012002200320042005200620072008

Fig. 3: Barometric pressure anomalies through september $2008(\mathrm{hPa})$

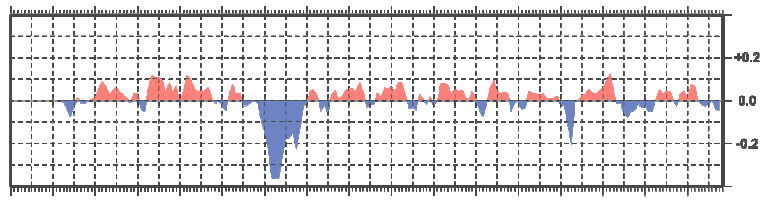

19921993199419951996199719981999200020012002200320042005200620072008

Fig. 4: Sea level anomalies through september 2008 (m)

Table 1: Significant parameters for the sea level situation in the Tuvalu area

\begin{tabular}{lll}
\hline Parameters & Values & Comments \\
\hline $\begin{array}{l}\text { Length of data } \\
\text { Sea level trend }\end{array}$ & $\begin{array}{l}15 \text { years } \\
+5.9 \mathrm{mM} \mathrm{year}^{-1}\end{array}$ & $\begin{array}{l}\text { Not long enough yet } \\
\text { Very small change from } \\
\text { the previous months }\end{array}$ \\
$\begin{array}{l}\text { Sea level rise } \\
\text { Vertical land movement } \\
\text { Number of El Niño's } 4\end{array}$ & $-0.06 \mathrm{mM} \mathrm{year}^{-1}$ & $\begin{array}{l}\text { For the last 15 years } \\
\text { not significant } \\
\text { Including very severe } \\
\text { one and prolonged one }\end{array}$ \\
\hline
\end{tabular}

The plot in Fig. 2 shows the evolution of the shortterm sea level trends at the Funafuti SEAFRAME station, from one year after installation to the present. During that period, there were four El Niño events that took place, including a very severe one in 1997/98, which generated a significant sea level drop in Tuvalu area. The usual positive (rising) sea level trends were changed to negative values (falling) for several months due to the effect of the El Niño.

Is the rate of sea level rise accelerating?: The sea level rise issue is not really a new problem to our daily lives. But the real danger may be if the rate of sea level rise increases with time. The main question for us is to find out if sea level rise rate is accelerating in the recent past. If being the case, the real danger is getting closer and the Pacific islanders might need to find a new land to live for their future.

If we simply look at the sea level trends with time shown in Fig. 2, it is quite obvious that trends for Tuvalu are more or less horizontal since 1999 (once the length of data is stabilised for trends calculation). It clearly indicates that the sea level rise rate is not accelerating in the recent past or at least during the project period. It is also to be acknowledged, nevertheless that visually at least and at this stage, there is no clear evidence for acceleration in sea level trends over the course of the last century based upon the long-term data elsewhere. More precisely, Mitchell et al. ${ }^{[7]}$ stated that the acceleration assessment from world wide industrialisation over the last two centuries seems to be very slow to appear. Accelerations of the trends identified in their exercise are at best extremely small, at least on this evidence from just five available long data sets.

\section{DISCUSSION}

Can we predict sea level for the future?: Before we start the discussion, it is appropriate to know what sea level means first. The mean sea level can simply be defined as the arithmetic mean of hourly water heights observed over the 18.61 years period. Shorter series are specified in the name as monthly mean sea level and yearly mean sea level ${ }^{[12]}$. A noteworthy point here is that sea level is the results from the complicated combination of some influences such as: (i) Daily tides, (ii) Meteorological effects (atmospheric pressure and winds, evaporation, precipitation), (iii) Thermal effect (volume expansion of water due to global warming, melting land ice), (iv) Seismic activity (underwater earthquake, tsunami), (v) Oceanographic effects (for 
example, El Niño, Rossby waves, Kelvin waves, density changes) and (vi) Vertical land movement.

Due to this complex combination of several influences, sea level cannot be predicted. It was the main reason of setting up the Australian project in the Pacific region to monitor the sea level and to calculate accurate sea level trends. Based upon the reliable trends, a simple projection for the future may be made for planning and policy making purpose.

According to Pittock ${ }^{[11]}$, mean sea level is expected to rise, with some regional variations, by between 1 and $10 \mathrm{~mm}$ per year until well beyond 2100 . The preliminary results of Shum et al. ${ }^{[13]}$ indicate that the 20th century sea level rise in the Pacific Ocean is $1.7 \pm 0.1 \mathrm{mM}_{\text {year }}{ }^{-1}$. This analysis is based on tide gauge data with records 50 years or longer. Using multiple altimeter measurements, it is estimated that the sea level rise for the Pacific basin during $1985-1999$ is $2.4 \pm 1.5 \mathrm{mM}$ year ${ }^{-1}$, which compares well with tide gauge data analysis during the same time, $2.1 \pm 0.3 \mathrm{mM}$ year $^{-1}$.

Hay et $a l .^{[3]}$ presented a simple method for computing local projections of mean sea level rise for the future. To determine the practical implications of projection of global sea level rise, in particular islands and coastal regions, it is necessary to include both global and local components. For example, between 1990 and 2050, a rise in Funafuti is most likely to be 10 $\mathrm{cm}$, but there is also a $20 \%$ chance of exceeding $20 \mathrm{~cm}$ and $20 \%$ chance of being less than $4 \mathrm{~cm}$.

According to the latest IPCC summary for the policymakers $^{[5]}$, it is to be noted:

- That the estimated rate of sea level rise based upon thermal expansion of water, melting of glaciers and ice caps, Greenland ice sheets and Antarctic ice sheets is $1.1 \pm 0.5 \mathrm{mM}$ year $^{-1}$ between 1961-2003 and $2.8 \pm 0.7 \mathrm{mM}$ year $^{-1}$ between 1993-2003. It is indicated that the rate is faster during the last 10 years

- That the observed rate of sea level rise is $1.8 \pm 0.5 \mathrm{mM}$ year $^{-1}$ between 1961 and 2003 and 3.1 $\pm 0.7 \mathrm{mM}$ year $^{-1}$ between 1993-2003

- Whether the faster rate for 1993-2003 reflects decadal variability or an increase in the longer term trend is unclear. There is high confidence that the rate of observed sea level rise increased from the 19th-20th century

- The total 20th century sea level rise is estimated to be $17 \pm 5 \mathrm{~cm}$

- This new report says that global warming is "very likely' man-made. This is the most powerful language used by the world's leading scientists

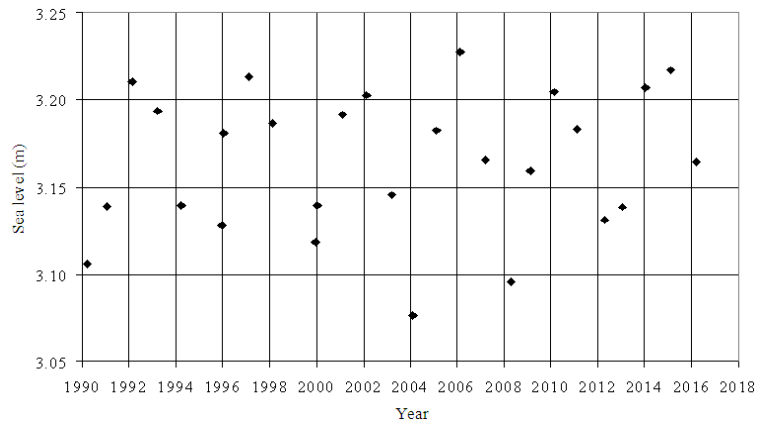

Fig. 5: Predicted highest tides in Tuvalu for every year

Although the prediction of future sea level is impossible, the main component of sea level (daily tides) is predictable. The tide is due mainly to the influence of the Sun and the Moon and some seasonal effects allow us to calculate the highest predictable level each year. It is primarily due to the ellipticity of the orbit of the Earth around the Sun and that of the Moon around the Earth. It is resulting in a point at which the Earth is closest to the Sun, combined with a spring tide in the usual 28-day orbit of the Moon around the Earth.

Figure 5 shows that the highest predicted level, $3.26 \mathrm{~m}$, over the period 1990-2016 was reached at 17:26 h local time on 28 February 2006 in the Tuvalu area. Water levels on 26 and 27 February are also higher than $3 \mathrm{~m}$ above the reference level of the tide gauge. Again, during 18 and 21 March 2006, water levels in Tuvalu are higher than $3.1 \mathrm{~m}$. This particular period is near the equinox (the Sun is closest to the Earth). The vernal equinox is the point where the Sun crosses the Equator from south to north and it occurs at about 21 March every year.

There is an apparent fluctuation in these annual predicted highest tides with a period of about $4 \frac{1}{2}$ years. This unusual periodicity has been observed elsewhere in semi-enclosed embayments like Funafuti and has been ascribed to interactions between the major tidal components.

Hunter's ${ }^{[4]}$ analysis is based on two sets of data; one from the University of Hawaii Sea Level Centre (UHSLC) and the other from NTC-BoM. It covers the years 1978-2001. The analysis indicates a rate of rise of $0.8 \pm 1.9 \mathrm{~mm} \mathrm{year}^{-1}$ relative to the land. There is a $68 \%$ probability of the rate of rise being between -1.1 and $2.7 \mathrm{mM}$ year $^{-1}$.

The second estimate, based on a rejection of data affected by El Niño Southern Oscillation (ENSO) events, is a rate of rise of $1.2 \pm 0.8 \mathrm{mM}_{\text {year }}{ }^{-1}$ relative to the land. There is a $68 \%$ probability of the rate of rise being between 0.4 and $2.0 \mathrm{mM}$ year ${ }^{-1}$. 
These estimates of relative sea level change at Funafuti are not directly comparable with IPCC estimates of global sea level rise during the 20th century, which is $1-2 \mathrm{mM}$ year $^{-1}$. But they are of similar magnitudes.

Hunter ${ }^{[4]}$ also tries to show that the uncertainty in sea level trend estimated from the data collected by NTC-BoM since 1993 is $\pm 13.7 \mathrm{mM}_{\text {year }}{ }^{-1}$. This data set is of little value in drawing any conclusions about long-term sea level rise mainly because of the relatively short record period and the effect of ENSO related events. More accurate estimates of sea level change at Funafuti will have to wait until a longer span of data has been collected. It is important that a continuing record of sea level be collected.

When we discuss the data length for trend calculations with reasonable certainties, it is appropriate to introduce a term called Node Cycle. It is a period of approximately 18.61 Julian years required for the regression of the Moon's nodes to complete a circuit of $360^{\circ}$ of longitude. It is accompanied by a corresponding cycle of changing inclination of the Moon's orbit relative to the plane of the Earth's equator, with resulting inequalities in the rise and fall of the tide and speed of the tidal currents ${ }^{[12]}$

According to Rockville ${ }^{[12]}$, the specific 19-year period is adopted as the official time segment over which tide observations are taken and reduced to obtain mean values for tidal datum. It is necessary for standardisation because of periodic and apparent secular trends in sea level, that is, non-periodic tendency of sea level to rise, fall or remain stationary with time, technically, it is the slope of a least-squares line of regression through a relatively long series of sea level values. For this reason, the Australian project is set to run four five-year phases, in total of 20 years for the whole project. The project is in its final phase now.

Going back to the Tuvalu issue, a longer sea level record is also available at Tuvalu from the Funafuti gauge operated by the University of Hawaii (UH) from 1977 until the end of 1999; about 22 years of data. The UH data exhibits a sea level rise of $+0.9 \mathrm{~mm} \mathrm{year}^{-1}$ over the period 1977 to the end of 1999. The UH gauge was designed to monitor the variability caused by El Niño and shorter term oceanic fluctuations, for which the high level of precision and the datum control demanded by the determination of sea level trend were not required. Hence, even with 22 years of data, the trend cannot be established without sizeable uncertainties $^{[10]}$.

Chittleborough et al. ${ }^{[1]}$ highlighted the several sources of error in the common method of estimating a long-term trend of sea level rise from water level measurements. Firstly, simple averaging of hourly sea level data to derive the monthly means will directly alias lower frequencies into the record. Secondly, the data interval of a monthly mean record is not constant, varying between 28-31 days. This is something we cannot avoid in general.

\section{CONCLUSION}

Erosion due to sea level rise is not the only issue in Tuvalu. Inundation will increase further inland together with saltwater intrusion to destroy underground the freshwater sources. According to McCracken of the US Global Change Research of Global Warming, a $1 \mathrm{~cm}$ rise in sea level can consume $1 \mathrm{~m}$ or more of beach width towards the sea ${ }^{[8]}$.

In this study, nearly 16 years sea level data from the Australian project was analysed and the sea level trends for Tuvalu area is $5.9 \mathrm{mM}$ year $^{-1}$ (until September 2008) which causes $9.14 \mathrm{~cm}$ sea level rise. If this rate continues, loss of land will be significant in the next 50 years.

While there is always likely to be debate over the scientific accuracy of sea level trends and the length of data used, the Tuvaluans cannot wait indefinitely to see the more accurate sea level rise results. It is still possible to address some of the uncertainties related to sea level monitoring and a better understanding of changes in Tuvalu. However, people are not too pessimistic as far as we are aware in the Pacific region. They are resilient and prepared to adapt to changes. They have been doing it for generations over the years and they will continue to do so.

\section{REFERENCES}

1. Chittleborough, J.B., W.M. Mitchell and W.D. Scherer, 2001. On the asymptotic trend evaluation of sea level from tide gauge records. Proceedings of the Science Component: Pacific Islands Conference on Climate Change, Climate Variability and Sea Level Rise, National Tidal Facility, Adelaide, ISBN: 10: 0957926405, pp: 1-4.

2. Flannery, T., 2005, The Weather Makers: The History and Future Impact of Climate Change. 1st Edn., The Text Publishing Company, Melbourne, ISBN: 10: 0713999217, pp: 384.

3. Hay, J.E., N. Mimura, J. Campbell, S. Fifita, K. Koshy, R.F. McLean, T. Nakalevu, P. Nunn and N. De Wet, 2003. Climate Variability and Change and Sea Level Rise in the Pacific Islands Region: A Resource Book for Policy and Decision Makers, Educators and other Stakeholders. 1st Edn., Ministry of Environment Japan and South Pacific Regional Environment Programme, Apia. http://www.sidsnet.org/pacific/sprep/climate/doc/0 lindex.htm 
4. Hunter, J.R., 2002. A note on Relative Sea Level Change at Funafuti, Tuvalu, Antarctic Cooperative Research Centre. University of Tasmania, pp: 25. http://staff.acecrc.org.au/ johunter/tuvalu.pdf

5. Intergovernmental Panel on Climate Change, 2007. Climate Change 2007: The Physical Science Basis, Summary for Policymakers, Cambridge University Press, $\quad$ Cambridge, $\quad$ pp: 21. http://news.bbc.co.uk/1/shared/bsp/hi/pdfs/02_02_ 07_climatereport.pdf

6. Menard, H.W., 1986. Islands. 1st Edn., Scientific American Library, New York, ISBN: 10: 0716750171, pp: 230.

7. Mitchell, W., J. Chittleborough, B. Ronai and G.W. Lennon, 2000. Sea level rise in Australia and the pacific. Proceedings of the Science Component: Pacific Islands Conference on Climate Change, Climate Variability and Sea Level Rise, National Tidal Facility, Adelaide, pp: 47-57.

8. Moore, C.A., 2002. Awash in a Rising Sea, International Wildlife.

http://www.nwf.org/internationalwildlife/article.cf $\mathrm{m}$ ? articleId $=15$ \&issue $\mathrm{Id}=3$

9. National Tidal Centre, 2008. Monthly data report: September 2008, South Pacific Sea Level and Climate Monitoring Project, Adelaide. http://www.bom.gov.au/ntc/IDO60101/IDO60101. 200809.pdf

10. National Tidal Facility, 2006. Pacific country report on sea level and climate: their present statetuvalu, South Pacific Sea Level and Climate Monitoring Project, Adelaide. http://www.bom.gov.au/ntc/IDO60033/IDO60033. 2006.pdf
11. Pittock, A.B., 1999. Assessing risk to the pacific island states from climate change and sea level rise. Proceedings of the Third SPREP Meeting on Climate Change and Sea Level Rise in the South Pacific Region, South Pacific Regional Environment Programme, pp: 167-187.

12. Hicks, S.D. R.L. Sillcox, C.R. Nichols, B. Via and E.C. McCray, 199. Tide and current glossary, national ocean service, NOAA, US Department of Commerce.

http://tidesandcurrents.noaa.gov/publications/gloss ary2.pdf

13. Shum, C.K., C.Y. Zhau, H.Z. Tseng and P. Woodworth, 2001. 20th Century sea level change in the pacific basin. Proceedings of the Science Component: Pacific Islands Conference on Climate Change, Climate Variability and Sea Level Rise, National Tidal Facility, Adelaide, pp: 83-88.

14. Singh, A. and T. Aung, 2005. Effect of barometric pressure on sea level variations in the pacific region. South Pacif. J. Natural Sci., 23: 9-15. DOI: 10.1071/SP05002 